BohusLaVa Gregorová

Matej Bel University, Banská Bystrica, Slovakia

\title{
Tourism as an Instrument of Economic Development of the Banská Bystrica Self-Governing Region
}

\begin{abstract}
The paper focuses on the evaluation of regional tourism in terms of its economic development potential. Based on selected economic indicators (e.g. registered unemployment rate, capacity and performances of accommodation facilities, average number of employees and average nominal wage), we analyse the position of the territory in the regional structure of Slovakia and describe factors that determine the development of the region (location, absence of large cities, poor transport infrastructure). Via valorising the natural and anthropogenic assumptions we evaluate the potential of the territory in the context of the possibilities of tourism development in it. Valorisation was carried out in relation to the main recreational activities, where the aggregate value of the potential expresses precisely the possibilities of developing recreational activities in the studied area. The most developed are the districts of Banská Bystrica and Brezno, forming the Horehronský tourism region. The less developed region with untapped tourism potential is Pohronský region, represented by the districts of Zvolen, Žiar nad Hronom, Žarnovica, Banská Štiavnica and Detva. The Gemerský region (the Rimavská Sobota and Revúca districts) shows the greatest difference between the potential of the territory and the current state of the level of tourism development. The least developed area with the lowest tourism potential is the Ipelský region (districts Krupina, Velký Krtíš, Poltár and Lučenec). Based on selected statistical indicators related to tourism (Baretje and Defert index, Schneider index, Charvat index) we evaluate the current state of development of tourism in the studied area. These approaches are complemented by a historical-geographic analysis of the development of the territory, which completes the image of the limits of development of the Banská Bystrica self-governing region.
\end{abstract}

Key words: Banská Bystrica; development; economy; self-governing region; tourism

Received: 25 October 2017

Accepted: 9 May 2018

\section{Suggested citation:}

Gregorová, B. (2018). Tourism as an Instrument of Economic Development of the Banská Bystrica self-governing region. Przedsiębiorczość - Edukacja [Entrepreneurship - Education], 14, 245-259. DOI: $10.24917 / 20833296.14 .18$ 


\section{Introduction}

Slovakia belongs to the countries with the fastest growing economy in Europe after 2000. However, the economy did not grow evenly in all regions of the country. A relatively marked slowdown in growth rates can be identified in case of the Banská Bystrica self-governing region.

Therefore, the aim of the paper was to analyse the potential, possibilities and limits of the region's economic development in relation to tourism. The analysis itself was based on the assessment of selected economic factors such as the registered unemployment rate, the capacity and performance of accommodation facilities, the average number of employees and the average nominal wage. All figures refer to December 31, 2015 and have been downloaded from the STATdat and DATAcube databases published by the Statistical Office of the Slovak Republic. The time inconsistency of the data was the reason for using the data only for 2015, as all the necessary data already existed just for this period. In the case of the employment indicator in tourism we have to deal with one problem. The data are divided into two categories - the average number of employees in 1) accommodation and catering services, and 2) entertainment and recreation.

The spatial framework of research was supplemented by the calculation of basic indexes and indicators (Baretje and Defert index, Schneider index, Charvat index) which documented both the degree of development and the intensity of tourism development in the individual districts of the region. Based on the recreational intensity index, we tried to uncover the relationship between its potential and the opportunities for tourism development. The results were described verbally, as well as visualised as tabular and cartographic outputs.

Quantitative (mathematical, statistical, cartographic) methods have been supplemented by a historical and geographic analysis of the development conditions of the districts of the region in order to obtain a comprehensive picture of its development, current state and possibilities of further progress in the context of tourism development.

\section{The current state of the problem under consideration}

In the post-1989 period, differences in the development potential of the various regions started to appear and, due to several factors, regional disparities increased greatly. Several authors (Blažek, Csank 2007; Hampl 2005; Korec et al. 2005; Rusnák, Korec 2013; Ženka et al. 2014) draw attention to this problem, while in geographical literature in Slovakia, but also in Poland and Hungary, identified can be a number of work that assess the potential of tourism in lagging regions in terms of their potential economic development (e.g. Pawlusinski, Piziak 2009; Rosič, Klamár 2009).

Personally, we have only recently addressed the issue of the economic impact of tourism on the development of the regions, with the first results of the study being presented at the conference "Current Issues of Tourism" held in February in Jihlava in the Czech Republic (Gregorová, Korec 2017). Another suggestion for us was a paper entitled "Several comments on the interpretation of the heterogeneity of the regional structure of the Banská Bystrica self-governing region” (Korec, Gregorová, Baran 2017). The conclusions of the two papers raised many questions that prompted us to further study and try to explore the Banská Bystrica self-governing region in the context of its possible economic 
development and development of tourism.

We can conclude that the region has a heterogenous level of tourism potential, but it does not have any legislative guidelines that would govern the investments in its development. The only conceptual binding document is the Economic and Social Development Program of the Banská Bystrica self-governing region 2015-2023. But there is no concept of tourism development (e.g. Košice, Bratislava or Nitra self-governing region have it), so the region is probably managed by strategic documents at national level.

Position and geographical characteristics

of the Banská Bystrica self-governing region

The Banská Bystrica self-governing region is thanks to its area of $9,455 \mathrm{~km}^{2}$ the largest higher territorial unit in Slovakia, occupying $19.28 \%$ of the country's area. It is located in the central and southern part of the territory of Slovakia and neighbouring to the west with Nitra region, to the north with Trenčín, Žilina and Prešov self-governing region, and in the east with Košice region. The southern border is common with Hungary (see map 1).

Map 1. Position of the Banská Bystrica self-governing region within Slovakia

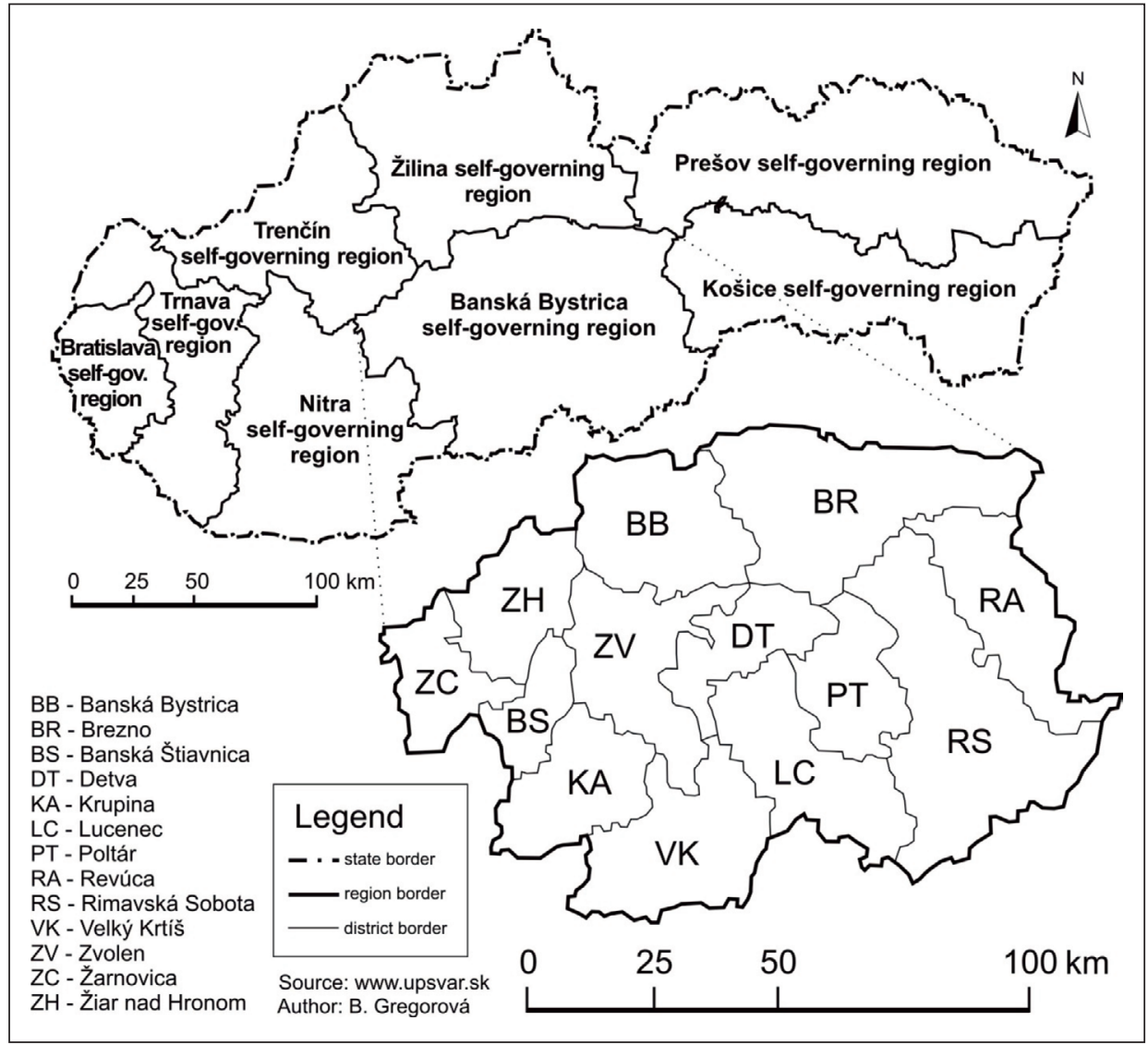

Source: www.upsvar.sk 
The Banská Bystrica self-governing region also has the most varied and most diversified surface among all regions of Slovakia. The lowlands in the form of Juhoslovenská kotlina, Zvolenska and Žiarska kotlina slowly pass into the hills of the Slovak Rudohorie or Slovak Stredohorie and end at the highlands stage in the Low Tatras. This complex relief greatly determines the primary potential of the area and thus its economic use.

The region consists of 13 districts, comprising 516 municipalities, of which 24 have the status of a city. However, in terms of the number of inhabitants, which is 653,024 (as of December 31, 2015), which is $12.03 \%$ of the population of Slovakia, the region is in fifth place. Regions with less inhabitants are only the Bratislava, Trnava and Trenčín self-governing regions (The Statistical Office of the SR, 2017). The population density is also low, reaching 69 inhabitants per $\mathrm{km}^{2}$ (Table 1). Similarly, the natural increase and respectively decline is also impeded in the region - in 2015 a decline of 1,167 inhabitants was observed.

Table 1. Basic data on the districts of the Banská Bystrica self-governing region (31.12.2015)

\begin{tabular}{|l|c|c|c|c|}
\hline \multicolumn{1}{|c|}{ District } & Population & $\begin{array}{c}\text { Area of the } \\
\left.\text { district } \mathbf{( k m}^{2}\right)\end{array}$ & $\begin{array}{c}\text { Population } \\
\text { density }\end{array}$ & $\begin{array}{c}\text { Population } \\
\text { living in urban } \\
\text { areas }\end{array}$ \\
\hline Banská Bystrica & 110,920 & 809.4 & 137 & 78,758 \\
\hline Banská Štiavnica & 16,314 & 292.3 & 56 & 10,210 \\
\hline Brezno & 62,616 & 1265.2 & 49 & 21,215 \\
\hline Detva & 32,505 & 449.2 & 72 & 22,499 \\
\hline Krupina & 22,530 & 584.9 & 39 & 9,374 \\
\hline Lučenec & 74,106 & 825.6 & 90 & 38,786 \\
\hline Poltár & 21,930 & 476.2 & 46 & 5,738 \\
\hline Revúca & 40,124 & 730.3 & 55 & 22,967 \\
\hline Rimavská Sobota & 84,577 & 1471.1 & 57 & 36,023 \\
\hline Velký Krtíš & 44,489 & 848.2 & 52 & 13,855 \\
\hline Zvolen & 68,932 & 759 & 91 & 47,865 \\
\hline Žarnovica & 26,540 & 425.3 & 62 & 13,854 \\
\hline Žiar nad Hronom & 47,441 & 517.7 & 92 & 24,789 \\
\hline Banskobystrický VúC & $\mathbf{6 5 3 , 0 2 4}$ & $\mathbf{9 4 5 4 . 4}$ & $\mathbf{6 9}$ & $\mathbf{3 4 5 , 9 3 3}$ \\
\hline
\end{tabular}

Source: The Statistical Office of the SR (2017)

The largest city in terms of the number of inhabitants is Banská Bystrica (level 3), Zvolen and Lučenec are cities of level 4, and the remaining cities except the Rimavská Sobota are at level 6. (Atlas of the Slovak Republic, 2002). Small towns and rural villages are concentrated in valleys along major communication axes and watercourses. There are also two areas of the distant Kopanice settlement, the region of Slovak Rudohorie and Krupinská planina, and the Novobanská štálová area (Baran, Bašovský 1998).

Only $17.3 \%$ of agricultural land and $11.7 \%$ of arable land are in the region (December $31,2015)$. In this case, however, it must be noted that up to $54 \%$ of the agricultural land of the region is located in 5 districts of the southern sub-region (Velký Krtíš, Lučenec, Poltár, Rimavská Sobota and Revúca). The Pohronské kotliny (basins) are much less important for their primary potential (Lukniš 1985). 
After 1989, a number of industrial enterprises ceased to adapt to the conditions of the global market economy. This phenomenon concerned particularly the southern part of the Banská Bystrica self-governing region. In 2015 only 52,370 inhabitants of the region worked in the industry sector, representing only $10.3 \%$ of all employed in industry in Slovakia. Also, the sales for own output and goods in industry in the given year were low, worse in this sense was only the Prešov self-governing region (The Statistical Office of the SR, 2017).

Thanks to its location in the central part of Slovakia, the region has a transit character (despite the complex geomorphological structure). The mainstay of traffic system is the road and rail transport. The backbone of the road network is speed communication R1 and sections R2 and R3, which are only partly completed. The extension of the R7 route in the direction of Nové Zámky - Velký Krtís - Lučenec was additionally supplemented on the basis of the government resolution in 2003. Within the railway transport, the territory of the region includes the national and regional importance. An important railway junction is Zvolen, through which the most important route of the region passes, the so-called south move: Leopoldov - Kozárovce - Zvolen - Lučenec - Košice. The regional routes are Zvolen - Banská Bystrica - Žilina, Zvolen - Banská Bystrica - Margecany and Zvolen - Šahy - Štúrovo (Program of Economic and Social Development of the Banská Bystrica self-governing region 2015-2023).

\section{Historical and geographic context of the development of the Banská Bystrica self-governing region}

The territory of the Banská Bystrica self-governing region (within its current borders) has never formed a single unit in the past, whether in administrative, demographic, economic or transport terms. Historically, we identify two distinctly evolving sub-regions, and this inner differentiation manifests itself today.

Most of the territory of the northern "Pohronský sub-region" was part of the Zvolen district (actually Zvolenská stolica), which was a stable administrative unit in terms of its definition; and its boundaries were not changed for several centuries. Relations and connections between settlements have acquired a "radial-concentric" character, with the centre of the territory being Zvolen and later Banská Bystrica. The economic development of the northern part of the sub-region was based on extensive mining activities, resulting in the creation of several free royal towns. After the decline in mining activity, the industry was located in this region (particularly heavy industry) for strategic, as well as economic reasons. During the socialist era, for example, the Ironworks in Podbrezová, the paper mill in Harmanec, the cement factory in Banská Bystrica, the aluminium factory in Žiar nad Hron, the manufacturing in Detva and the chemical industry in Slovenská Lupča and Dubová. After 1989, most of the enterprises have been able to transform and with greater or lesser success still operate (Korec, Gregorová, Baran 2017).

The southern sub-region (Ipel'sko-Slanský in the sense of Lukniš 1985) historically belonged to Hontianská, Novohradská and Gemersko-Malohonská župa. These, under the pressure of two distinct centres, administrative (Budapest) and economic (the heavily developed mining area in the north - Kremnica, Banská Bystrica, cities in Slovak Rudohorie), never worked very well. All old road traffic and its downstream railways had a north-south direction and during the Hungarian period no connecting route of the west-east orientation was created, as it did not require political, administrative 
or economic interests (Bašovský et al. 1987). After 1918 (the forming of Czechoslovakia), the region was in a peripheral position and this status persists to this day. Another specific feature of the southern sub-region in terms of location is its borderlines. It is crossed by the ethnic Slovak-Hungarian border and this territory formed a connecting line or a transit belt between the mining, industrial centres of the Slovak Rudohorie and the south-lying agricultural areas and iron industry centres in Hungary. The borderline was negatively manifested not only during World War II (most of this territory after the Vienna Arbitration came to Hungary) but also after it, as the Czechoslovak government did not place industrial enterprises in the border area for strategic reasons. The industry was therefore scattered into sites with few deposits, mainly non-metallic raw materials. All of these factors were conditioned by the slow growth of towns, with the exception of Lučenec, which currently represents the centre of the $4^{\text {th }}$ level, together with Zvolen (Korec, Gregorová, Baran 2017).

\section{Potential of the Banská Bystrica self-governing region in relation to tourism}

From the natural point of view, the northern part of the region is typical for mountains and secluded valleys characterised by hilly to high reliefs, which create small nuclear areas connected by narrow breakwaters of the Hron valley. It is the most widespread in the area of the Zvolen basin. Much of the territory thus occupies massive, deeply cut and hardly accessible hills covered by large forests (Lukniš 1985). Rural settlements originated in metal mining or metallurgy industry which disappeared and allowed the development of cottages and tourism. The ridges of the Low Tatras, Starohorské, Kremnické, Štiavnické, or Veporské vrchy or Polana and Velká Fatra are suitable for the development of rural tourism, hiking, cycling, skiing, cross-country skiing, and climbing.

In 2015 there were 19 cableways, 84 ski lifts, 109 slopes and 11 traverses in the territory of the Banská Bystrica self-governing region. The total length of downhill skiing runs exceeded $106 \mathrm{~km}$. The length of the $195 \mathrm{~km}$ trails and the marked hiking trails is 3,388 km (Program of Economic and Social Development of the Banská Bystrica self-governing region 2015-2023).

Mountain torrents, Hron itself and water reservoirs are used for the development of water sports and water tourism.

The southern part of the region is characterised by a high proportion of lowland hillsides and lower hillsides. The core area of the southern sub-region is the Juhoslovenská kotlina, densely settled in the northern part. This space represents the background of the Slovak Strednohorie and the Slovak Rudohorie. Most of the area of the Juhoslovenská kotlina lies in the lowland, so it is relatively warm and has plenty of sunny days (Lukniš 1985). Due to its west-eastern shape, it is mainly used as a link between the regions of Bratislava and Košice. Its transit character also supports the location of pipeline transport (Družba pipeline, Bratstvo gas pipeline).

In the southern sub-region, no significant seat has historically developed, and its density of settlement is also low. Such a landscape is suitable for the development of rural tourism and agro-tourism, undisturbed hiking, cycling, water stays and water sports (thermal swimming pools).

The quality of the natural environment of the self-governing region is very high. In its territory it reaches up to 5 national parks with its part or protective zone, namely 
Low Tatras, Vel'ká Fatra, Muránska planina, Slovak Paradise and Slovak Kras. Important areas in the region are the protected areas: Polana (also UNESCO biosphere reserve), Štiavnické vrchy, Cerová vrchovina and other natural reserves, natural monuments, caves and slopes.

The water reservoirs Ružiná, Teplý vrch, Málinec, Kurinec and Hriňová are used for recreation. A specific recreational and landscape-aesthetic value has the water reservoirs (so called tajchs) in Banská Štiavnica. The occurrence of natural healing resources has enabled the development of spa in the region. Spa in Dudince, Brusno and Sliač, the regional spa in Sklené Teplice and in Kováčová achieved national importance. Thermal springs made good condition for thermal spas; the most famous are located in Kremnica, Vyhne and Dolná Strehová. Non-thermal swimming pools were built within recreational zones in the towns of Banská Bystrica, Zvolen, Rimavská Sobota, Lučenec and Poltár.

Cultural and historical attractions include castles, ruins of castles, chateaus, mansions, temples, museums, and folk architecture reserves. The historical city of Banská Štiavnica, together with the technical monuments of its surroundings, as well as the wooden church in Hronsek (wooden temples in the Slovak part of the Carpathian arch) are considered the most valuable and are listed in the UNESCO World Heritage List.

Centres of the cities are protected as city monument reserves - Banská Bystrica, Banská Štiavnica, Banska Belá, Nová Baňa, Kremnica, Zvolen, or the town monument zones - Rimavská Sobota, etc. Reserves of folk architecture are located in the villages of Špania Dolina and Sebechleby, part of Stará Hora. The most important castle, and respectively ruins include Slovenská Lupča, Modrý Kameň, Šášov, Divín, Muráň, Filakovo, Čabrad and Šomoška. Attractive sights include, for example, Zvolen Castle, Víglaš Chateau and Svätý Anton or the monastery in Hronský Beňadik. Discovering cultural and historical sites, visiting museums and galleries, as well as various events, influence the development of cultural tourism. Major cultural institutions are, for example, the Museum of the Slovak National Uprising in Banská Bystrica, Museum of mining in Banská Štiavnica, Museum of Coins and Medals in Kremnica, the Forest and Wood Museum in Zvolen and other regional ethnographic museums. Famous theatre institutions are located mainly in a regional town, in Banská Bystrica - the State Opera, the Puppet Theatre at the crossroads, the Studio of Dance, or the Theater of Jozef Gregor Tajovský in Zvolen.

\section{Assessing the potential of the territory of the Banská Bystrica}

self-governing region

The Banská Bystrica self-governing region has good potential for the development of active tourism. The diversity and richness of the relief in the form of caves (Harmanecká and Bystrianska cave), the amount of mineral springs, watercourses and water areas, the rotation of natural and cultural landscapes, together with anthropogenic attractions, predestines this territory to the boom of the main forms of tourism - summer tourism and water stays, winter tourism and winter sports, spa and health tourism, urban and cultural tourism, rural tourism and agro-tourism (Tourism Development Strategy 2020).

The significance of these forms, for which the whole Slovakia, as well as the studied area have the best assumptions, is reflected in their large share of the region's tourism, as well as its economic benefits. Key issues appear both in foreign and domestic tourism, with dominance of foreign tourism (Rosič, Klamár 2009). 
Map 2. Tourism regions of the Banská Bystrica self-governing region

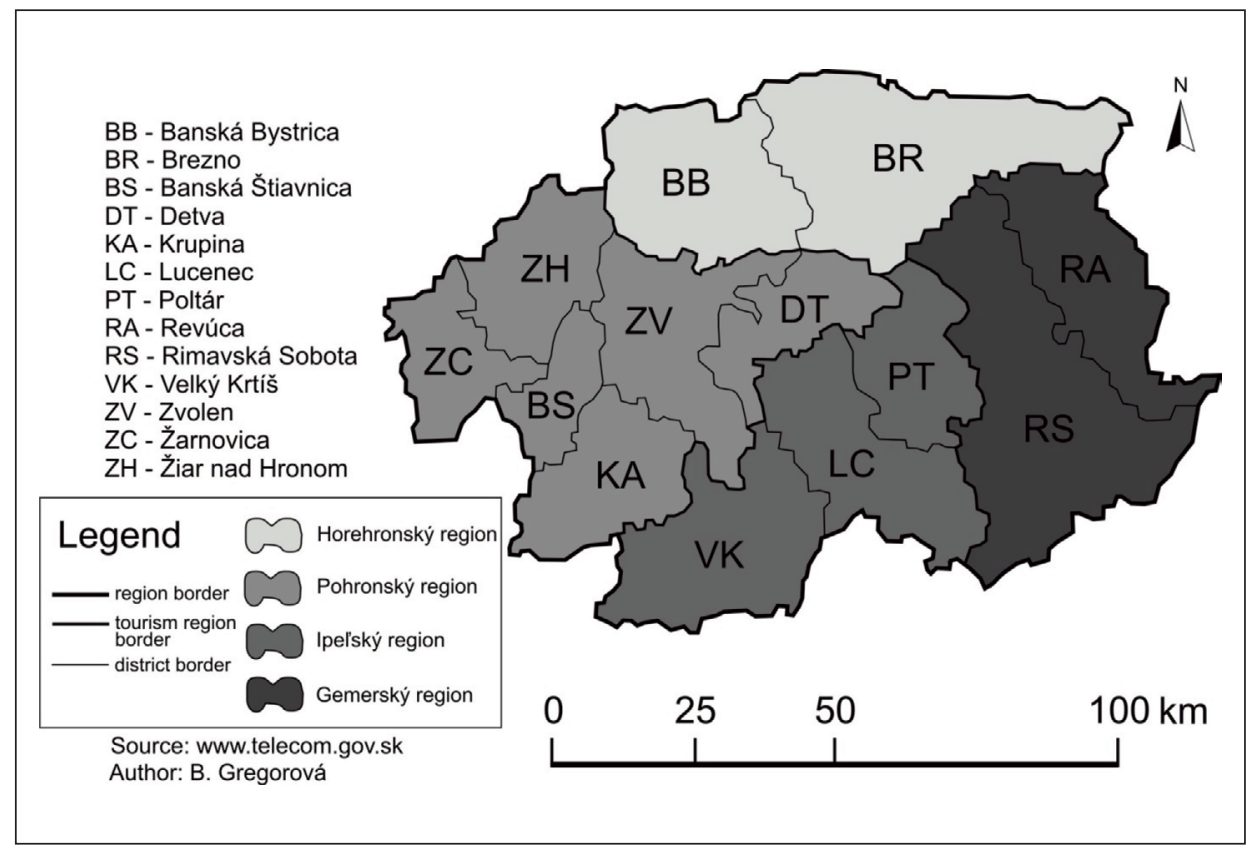

Source: www.telecom.gov.sk

In assessing the current situation and the development of tourism opportunities in the studied area, we used the analysis of its potential, which we applied at the regional level. The Banská Bystrica self-governing region consists of four regions of tourism: Horehronský, Pohronský, Ipel’ský and Gemerský region, except Rožňava district (map 2).

The assessment itself in the form of valorisation allowed us to evaluate the quality of tourism development conditions in individual regions and to categorise them according to their importance. The potential has been assessed in relation to the natural environment, the anthropogenic environment and the quality of services (Table 2).

Table 2. Evaluation of the potential of tourism regions of the Banská Bystrica self-governing region

\begin{tabular}{|l|c|c|c|c|}
\hline $\begin{array}{c}\text { Name of tourism } \\
\text { region }\end{array}$ & $\begin{array}{c}\text { Value of natural } \\
\text { potential } \\
\text { (weighted) }\end{array}$ & $\begin{array}{c}\text { Value of } \\
\text { anthropogenic } \\
\text { potential } \\
\text { (weighted) }\end{array}$ & $\begin{array}{c}\text { Value of service } \\
\text { potential } \\
\text { (weighted) }\end{array}$ & $\begin{array}{c}\text { Total potential } \\
\text { value } \\
\text { (weighted) }\end{array}$ \\
\hline Horehronský & 198 & 131 & 38 & 367 \\
\hline Pohronský & 169 & 116 & 24 & 309 \\
\hline Ipel'ský & 90 & 60 & 24 & 174 \\
\hline Gemerský & 137 & 79 & 14 & 230 \\
\hline
\end{tabular}

Source: processed by author, based on Regionalization of Tourism in the Slovak Republic, 2005

The highest values (367 points) are reached by the Horehronský region. It is undoubtedly the most important tourist region in Central Slovakia, which is absolutely dominated by its attractiveness and uniqueness. This typically mountainous region has the 
best conditions for the development of winter sports in the Low Tatras, Kremnické vrchy and Slovenské Rudohorie. The most developed skiing centres are Chopok-south and Donovaly. The supraregional significance have the Mýto pod Dumbierom, Šachtičky, Tále, Krpáčovo, Telgárt. The biathlon area in Osrblie is suitable for the development of cross-country skiing. The rich natural potential is confirmed by the presence of Harmanecká and Bystrianska Cave. Numerous cultural and technical monuments increase the overall attractiveness of the region, which is of international significance (the Hronsek wooden church, the Čiernohronská railway in Čierny Balog, mining water basin in Špania dolina, the castle in Slovenská Lupča and the cultural traditions in Helpa).

The second most important region is Pohronský region (309 points). It has a strong potential linked to water resources, as well as a cultural-historical value, based primarily on mining traditions. The spa resorts Sliač, Kováčová and Sklené Teplice are of national importance only, but the water management system of the reservoirs (tajchs) around Banská Štiavnica is unique. The town together with Kremnica and Nová Baňa documents the strong tradition of mining in the region. Significant locations are also Zvolen, Svätý Anton, Víglaš, Detva, Hronský Beňadik and Dobrá Niva. Areas of Kremnické vrchy (Skalka-Krahule), Štiavnické vrchy, Slovenské rudohorie and Vtáčnik are used for recreation. The region has a national significance over the long term.

The most interesting is the Gemerský region. It shows the greatest difference between the potential and the real state of tourism development (in the long run, it is of national importance as well as the Pohronský region). These disproportions result from the poor economic development of the region and the unfinished technical or transport infrastructure. The recreational area of the region is situated in the Slovenské Rudohorie and Cerová vrchovina. The most important settlements are Rimavská Sobota, Revúca, Jelšava and Murán. Regional significance is given by resorts in the vicinity of the Kurinec and Teplý vrch reservoirs and the spa of Číž.

The least developed region of trans-regional importance (in long-term context) is Ipel'ský region. Most of the visitors are connected to the spa in Dudince. However, the potential of the region lies in the possibilities of developing rural tourism, wine-making or gastronomy, and it is possible to connect it to the Hungarian markets. In the region is located the Javorie Mountains, the Krupinská Planina, the Cerová vrchovina and part of the Slovak Rudohorie. Besides Dudince, the recreation centre Dolná Strehová and water reservoir Ružiná are also visited. The cultural monuments represent the castle of Modrý Kameň, the ruins Filakovo, Čabrad, Divín, as well as the monumental reserve of the folk architecture of Sebechleby - Stará Hora (Regionalization of tourism in Slovakia, 2005).

\section{Economic aspects of tourism in the Banská Bystrica self-governing region}

Under the influence of socio-economic changes in the conditions of renewed democracy and market economy differences in the development potential of individual regions were significant. In relation to tourism, we will document these facts on indicators relating to registered unemployment rates, the capacity and performance of accommodation facilities, the average number of employees in tourism and the average monthly nominal wage in tourism. All data are valid for December 31, 2015.

The registered unemployment rate reached more than $15 \%$ in the region, only the Prešov Region (16.3\%) was worse. In the districts, the smallest number of unemployed 
was in Banská Bystrica (8\%) and Zvolen (9.3\%). By contrast, the southern districts of Rimavská Sobota (27.4\%), Poltár (20.8\%), Revúca (19.9\%) and Lučenec (17.5\%) showed the highest number of unemployment.

In terms of the number of accommodation facilities, the Banskobystrický Region ranks third, behind the Žilina and Prešov regions. All types of accommodation facilities, which were 508 , had only 21,518 beds total. The Žilina Region had almost double the number of beds $(40,057)$, the Prešov region offered 32,291 beds, the Košice region 23,188 and the Bratislava 27,920 beds. We also find great differences at the district level. The Banská Bystrica district had 131 facilities and Brezno 86 in 2015. In the districts there are important mountain resorts such as Donovaly, Chopok-south, Mýto pod Dumbierom or Tále. On the other hand, the smallest number of recreational facilities functioned again in the southern districts, Poltár (9), Rimavská Sobota (14) and Lučenec (21). The same ranking can be observed in the case of bed capacity, more than 4,900 beds were available in the Banská Bystrica district, in Brezno it was 3,670. On the other side of the spectrum is the Poltár district with 206 beds, the Revúca district with 628 beds and the Velký Krtís district with 693 beds.

Regarding the number of visitors, the most visitors came to Bratislava region, up to $1,194,479$, then to Žilinský $(735,470)$, Prešovský $(642,706)$ and Banskobystrický region - 448,568 visitors. Large intra-regional differences within districts are also investigated for this indicator. The most visitors came to the Banská Bystrica district - 90,029 and spent there 214,019 nights. The second place is traditionally Zvolen with 80,377 visitors, who spent the night in the district up to 296,658 times. The third district of Brezno welcomed 65,592 visitors who spent 152,079 nights here. The fewest visitors were in Poltár (1,716), Žarnovica $(11,543)$ and Velký Krtís $(12,240)$. We have similar rank in the number of overnight stays in the districts. The least number of guests slept in the Poltár district (5,455 nights), then in Žarnovica district (25,544 nights) and Revúca (28,368 overnight stays).

More specifically, we will look at the employment indicator in tourism. Banskobystrický region in a long-term reduces the number of employees in accommodation and catering services, in 2015 it was only 1,620 people, which is the least of all regions. Relatively balanced employment is reported in the category of Arts, Entertainment and Recreation. There were 1,859 employees in the sector, and the region occupied fourth place (Figure 1).

Based on the previous analysis of the statistical indicators, we can state that the economic level of the Banská Bystrica region is low and the region is a less developed region of Slovakia. It has a high unemployment rate that cannot be eliminated by creating job opportunities linked to tourism services. The number of employees in tourism is the smallest among all regions of Slovakia. Despite its large size and high quality conditions for tourism development, there are not a large number of recreational facilities (third place among the regions), which also have less capacity and were built during the socialist period. Only by gradual reconstruction and redevelopment or training of staff can it achieve quality services of foreign companies. Therefore, tourism revenue, which amounted to about 30.5 million EUR in 2015, (www.statistics.sk, 22.10.2017), cannot stimulate the development of the region, and it lags behind the western more developed part of Slovakia. 
Fig. 1. Average registered number of employees in 2011-2015

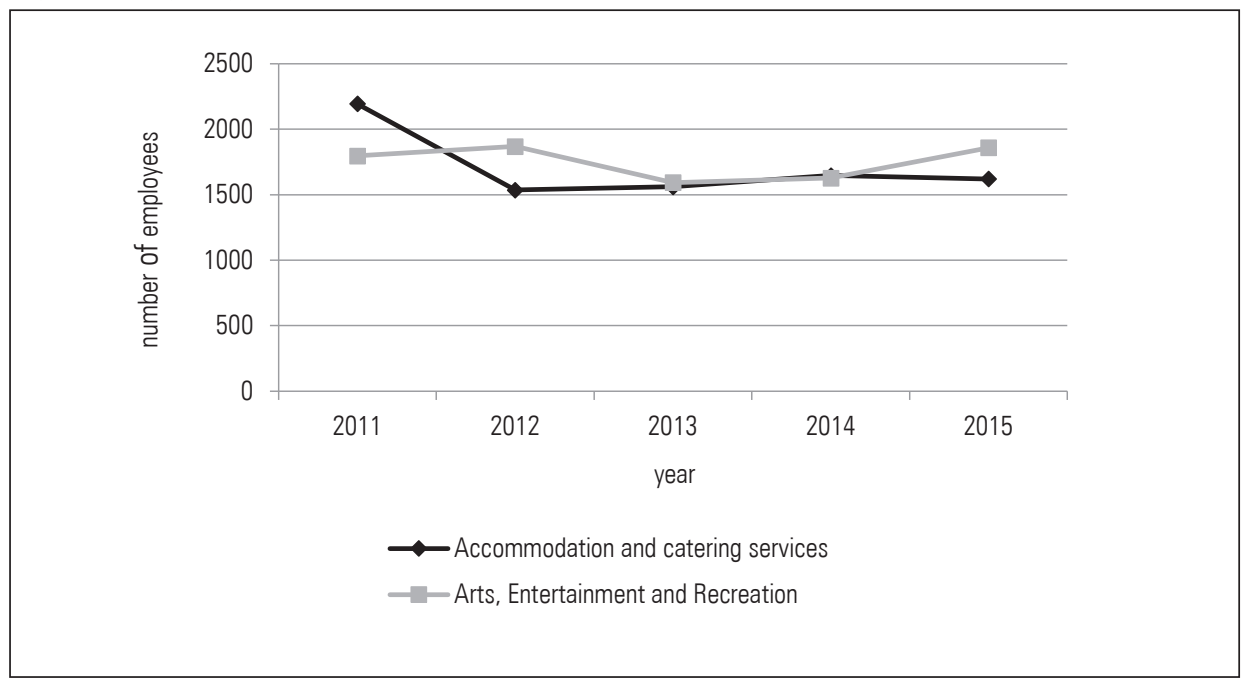

Source: The Statistical Office of the SR (2017)

\section{Conclusions}

The Banská Bystrica self-governing region development lags behind the Bratislava, Trnava, Trenčín and Nitra regions and in the regional structure of Slovakia has an unfavourable position. The most important factors behind this lag are the insufficient completion of transport infrastructure, the specific settlement and demographic characteristics of the region (low population density, absence of large cities, high share of the Roma population), low foreign direct investment and few vacancies, peripheral location and neighbourhood with less developed regions of Slovakia and Hungary, as well as internal polarisation - more developed northern districts and less developed south (Korec, Gregorová, Baran 2017).

Is it therefore possible for tourism to mitigate these gigantic differences between the northern and southern regions respectively, help to revive, to start its economy? To answer this question, we will try to obtain, on the basis of the analysis of several indexes and indicators (Table 3), which will direct us to the relationship between the degree of tourism development and the potential of the country, the possibilities or limits of the further development of tourism in the region.

Baretje and Defert index is the result of the share of the number of beds in the district and its inhabitants. The remaining two indexes (Schneider and Charvat) express the intensity of tourism in the surveyed area. They represent the share of the number of tourists and the number of inhabitants of the district.

An exceptional position has the Krupina district, which dominates in all indicators. There is Dudince Spa, characterised by high number of visitors. However, if we disregard Krupina in the evaluation (and thus prevent distortion and deformation of the conclusions), we would find that the dominant positions have Banská Štiavnica, Zvolen, Brezno and Banská Bystrica. Banská Štiavnica and Zvolen form the basis of the Pohronský region, which is now of transregional and in the long run of national importance. Žarnovica, 
Tab. 3. Selected indexes of the degree of tourism development of the Banská Bystrica self-governing region

\begin{tabular}{|l|c|c|c|}
\hline \multicolumn{1}{|c|}{$\begin{array}{c}\text { Index/ } \\
\text { Tourism region }\end{array}$} & $\begin{array}{c}\text { Baretje and } \\
\text { Defert index } \\
(\mathbf{\%})\end{array}$ & $\begin{array}{c}\text { Schneider index } \\
\mathbf{( \% )}\end{array}$ & $\begin{array}{c}\text { Charvat index } \\
\text { (\%) }\end{array}$ \\
\hline Banská Bystrica & 4.43 & 81.17 & 230.48 \\
\hline Banská Štiavnica & 8.61 & 146.92 & 351.14 \\
\hline Brezno & 5.78 & 105.33 & 305.86 \\
\hline Detva & 3.06 & 54.35 & 138.49 \\
\hline Krupina & 8.88 & 230.38 & 1543.87 \\
\hline Lučenec & 1.06 & 22.67 & 37.13 \\
\hline Poltár & 0.97 & 7.82 & 23.01 \\
\hline Revúca & 1.25 & 34.63 & 92.43 \\
\hline Rimavská Sobota & 1.42 & 27.43 & 110.11 \\
\hline Velký Krtíš & 1.87 & 27.51 & 83.20 \\
\hline Zvolen & 3.90 & 113.92 & 454.37 \\
\hline Žarnovica & 3.88 & 43.49 & 120.27 \\
\hline Žiar nad Hronom & 4.25 & 86.73 & 362.87 \\
\hline
\end{tabular}

Source: own calculations, based on database of the Statistical Office of the SR (2017)

Žiar nad Hronom and Detva represent the background of the region and, in order of the districts, they are placed sixth to eighth. Brezno and Banská Bystrica are of international importance. Their potential is mainly connected to the town of Banská Bystrica and the Low Tatras. The districts of the Gemer region of Rimavská Sobota and Revúca are approximately 10th and 11th. Rožňava district also belongs to this region, but it belongs to the Košice self-governing region. Rožňava, typical for its connection to mining, increases the region's potential and attractiveness. Ipel' as tourism region, represented by the aforementioned district of Krupina and the districts of Lučenec, Vel'ký Krtíš and Poltár reaches the lowest values. Poltár is always in the last place in all the indicators considered.

The last indicator we assess is the index of recreational intensity of districts. It is calculated as the share of the number of beds and the area of the district (see map 3). The highest recreational intensity is in Banská Bystrica (6.08). Followed by Banská Štiavnica (4.80), Žiar nad Hronom (3.89), Zvolen (3.54), Krupina (3.42) and Brezno (2.86).

The Horehronský region has reserves in making use of its potential, particularly in the eastern part of the Brezno district. Due to relatively high unemployment (12.52\%), investment in tourism development would also support the economic development of the district. However, two important factors have to be taken into account, namely the transport links between the territory of the district and nature conservation. Valley of Hron river is not a separate communication corridor, and the connection of the region with Turiec, Liptov or Gemer is possible only by crossing the mountain seats (e.g. Donovaly, Šturec, Vernár, etc.). The increase of the recreational intensity of the country by construction of tourism facilities must be realised with regard to ecological impacts in relation to the Low Tatras National Park. With regard to the Banská Bystrica district, its potential is to a large extent depleted and it is necessary to prevent the devastation and degradation of the natural environment, especially in Donovaly. 
Map 3. Index of recreational intensity of districts of the Banská Bystrica self-governing region

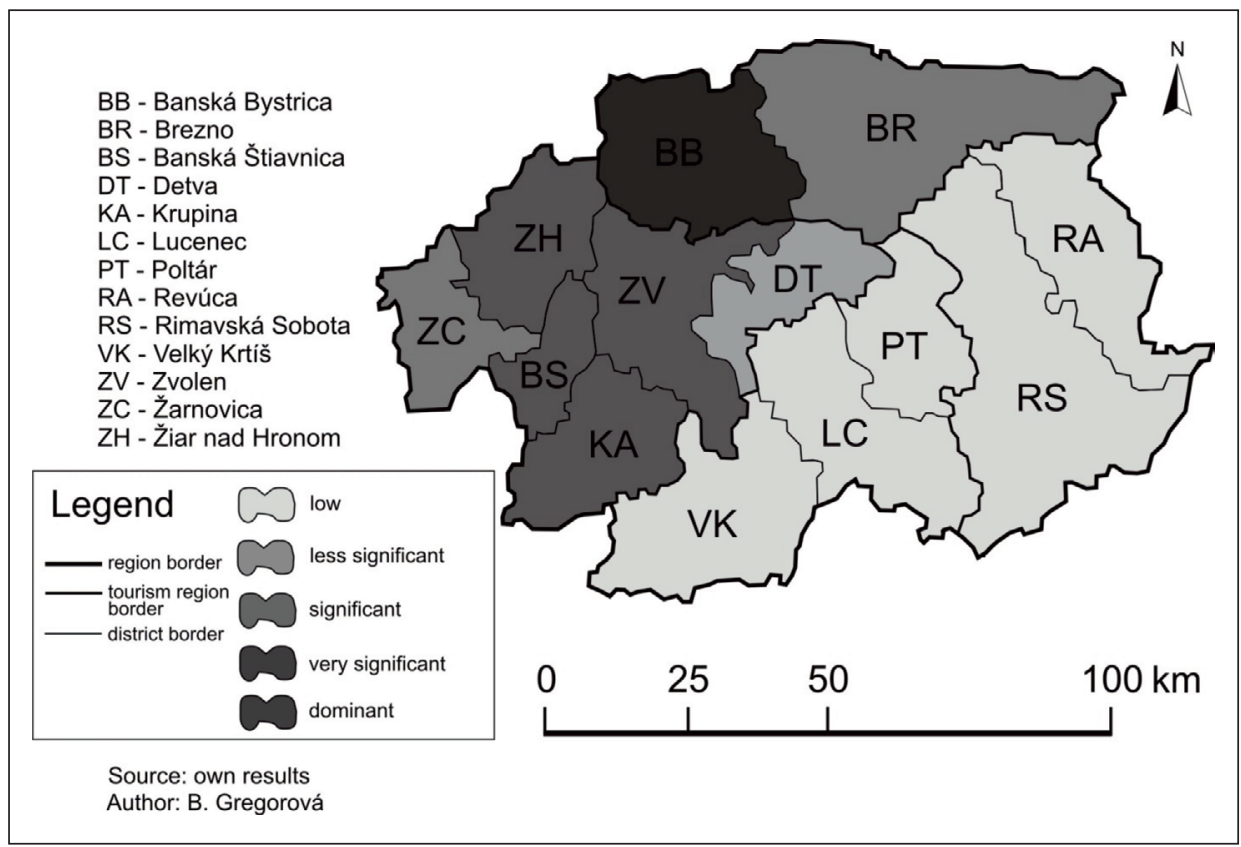

Source: own results

In the Pohronský region there is a great potential in the Kremnické and Štiavnické vrchy, i. e. in the districts of Žiar nad Hronom, Žarnovica and Banská Štiavnica. In particular, for the last mentioned district, the development of tourism has brought great impetus to economic development. Based on unemployment, we estimate (more than $16 \%$ in 2015) that there is enough free labor in the district. However, some spatial isolation slows down its development. Strong position of Zvolen within the Pohronský region derives from its location (the background of Banská Bystrica - the centre of the region and its position on the communication link with Bratislava), as well as infrastructure and economic development. In the similar position as Banská Štiavnica in the Pohronský region, is the district of Detva. It has far-reaching potential (Polana and Veporské vrchy) suitable for tourism development and rural tourism. After the downsizing of the manufacturing industry, district has to deal with relatively high unemployment (12.92\% in 2015), and the development of tourism would be one of the options.

Gemerský region, i. e. the districts of Rimavská Sobota and Revúca, have the highest unemployment, i.e. $19.97 \%$ and $27.42 \%$ respectively (in 2015). The region's potential is at the same level as in the case of the Pohronský region. These districts are in long-term undersized in terms of any investment. The recreational intensity of the area is very low (Rimavská Sobota 0.82 and Revúca 0.69). In particular, the northern part of the districts has a good natural potential. The area is suitable for the development of undemanding tourism, cycling (Stolické vrchy, Revúcka vrchovina) and rural tourism. Equally important in terms of cultural and cognitive tourism are mining monuments and attractions. 
The Ipel'ský region has only the basic potential for tourism development. All districts considered in this section are in the last places. The economic underdevelopment of the region (resulting from historical development and peripherality) will be very difficult to overcome by stimulating tourism.

Tourism can therefore support the regional competitiveness, but it is not a "cure" for all its economic problems. The region has many specific features, it is very polarised (developed northern parts and underdeveloped south), and it is hardly able to progress and develop without the state's financial support (for example, in the infrastructure), especially in the southern district.

\section{References}

Baran, V., Bašovský, O. (1998). Geografia sídiel. Banská Bystrica: FPV UMB.

Bašovský, O. et al. (1987). Juhoslovenské okresy v širšom geografickom kontexte a potenciál ich d’alšieho rozvoja. Geographica, 27, 15-51.

Blažek, J., Csank, P. (2007). Nová fáze regionálního vývoje v ČR? Sociologický časopis, 43, 945-965.

Gregorová, B., Korec, P. (2017). Cestovný ruch ako významná súčast' rozvojového potenciálu regiónu východné Slovensko. Folia Geographica. Article in print.

Hampl, M. (2005). Geografická organiza cespolečnosti v České republice: transformační procesy a jejich obecný kontext. Praha: Univerzita Karlova.

Korec, P. et al. (2005). Regionálny rozvoj Slovenska v rokoch 1989-2004. Bratislava: Geografika.

Korec, P., Gregorová, B., Baran, V. (2017). Niekolko poznámok k hodnoteniu a interpretácii heterogenity Banskobystrického samosprávneho kraja. Acta Geographica Universitatis Comenianae, 61, $113-144$.

Lukniš, M. (1985). Regionálne členenie Slovenskej socialistickej republiky z hladiska jej racionálneho rozvoja. Geografický časopis, 37, 137-163.

Pawlusinski, R., Piziak, B. (2009). Tourism potential and possibilities of its exploitation in the Subcarpathian (Podkarpackie) voivodeship. Folia Geographica, 49, 223-237.

Program hospodárskeho a sociálneho rozvoja Banskobystrického samosprávneho kraja 2015-2023. Retrieved from: https://www.enviroportal.sk/eia/dokument/232753

Regionalizácia cestovného ruchu $v$ Slovenskej republike. Retrieved from: http://www.telecom.gov.sk/index/index.php?ids=102432

Rosič, M., Klamár, R. (2009). The potential of tourism in the Prešov county regions. Folia Geographica, 49, 249-270.

Rusnák, J., Korec, P. (2013). Alternatívne koncepcie postsocialistickej transformácie. Ekonomický časopis, 61, 396-418.

Stratégia rozvoja cestovného ruchu do roku 2020. Retrieved from: http://www.telecom.gov.sk/index/index.php?ids=143964

Štatistický úrad SR. STATdata. DATAcube. Retrieved from: http://statdat.statistics.sk/ cognosext/cgibin/ cognos.cgi?b_action $=x t s . r u n \& m=$ portal $/$ cc.xts\&gohome $=$

Ženka, J. et al. (2014). Regional Competitiveness in Central European Countries: in Search of Useful Conceptual Framework. European Planning Studies, 22, 164-183.

Bohuslava Gregorová has been dealing with geography of tourism since 2006. She finished her $\mathrm{PhD}$ in the Department of Geography and Applied Geoinformatics of Prešov University in Prešov. At present she works in the Department of Geography and Geology of Matej Bel University in Banská Bystrica as an assistant professor of human geography. Since 2017 she has been working as the Head of the Department. She is specialised in the teaching economic geography, geography of tourism, religious geography, behavioural geography, geography of Slovakia. Her research interest 
is focused on spatial models of tourism, theory and methodology of tourism, urban tourism, use and application of GIS in tourism, history of tourism, pilgrimage tourism, regional development in tourism.

\section{Address:}

Matej Bel University

Faculty of Natural Sciences

Deapartment of Geography and Geology

Tajovského 40

97401 Banská Bystrica

e-mail: bohuslava.gregorova@umb.sk 